Didaktik : Jurnal Pendidikan Guru Sekolah Dasar, ISSN : 24775673

Sekolah Tinggi Keguruan dan IImu Pendidikan Subang

Volume IV Nomor 2, Desember 2018

\title{
PENGGUNAAN MODEL JIGSAW UNTUK MENINGKATKAN HASIL BELAJAR ILMU PENGETAHUAN SOSIAL PADA SISWA KELAS V (LIMA) SD NEGERI 2 PARUNGSARI KECAMATAN SAJIRA
}

\author{
Masni \\ SDN 2 Parungsari
}

\begin{abstract}
The concern that the enthusiasm of students in developing themselves individually can be threatened in the use of group work methods can be understood. This is because in group assignments carried out carelessly, sometimes students are not learning optimally, but they are too dominating or throw responsibility. The cooperative learning method must be made in such a way that each member in one group carries out his personal responsibilities because there is an individual scoring system. Students cannot simply take the value of their partner's efforts and each student's efforts will be rewarded according to the points of improvement. One model that can be used is the Jigsaw model. The problem that wants to be studied in this action research is whether jigsaw cooperative learning influences the learning outcomes of Social Sciences. This research is classroom action research which consists of several cycles. Each round consists of four stages, namely: design, activity and observation, reflection, and revision. The target of this study was the fifth grade students of Parungsari 2 Elementary School in the academic year 2011/2012. Data was obtained in the form of formative test results, observation sheets of teaching and learning activities. The results showed that students' learning achievement had increased from cycle I to cycle II, cycle I (64.71\%), cycle III (88.24).
\end{abstract}

Keyword: Cooperative Learning, Jigsaw, Social Science.

\begin{abstract}
ABSTRAK
Kekhawatiran bahwa semangat siswa dalam mengembangkan diri secara individual bisa terancam dalam penggunaan metode kerja kelompok bisa dimengerti. Hal ini dikarenakan dalam penugasan kelompok yang dilakukan secara sembarangan, siswa bukannya belajar secara maksimal, melainkan belajar mendominasi ataupun melempar tanggung jawab. Metode pembelajaran kerja sama distruktur sedemikian rupa sehingga masing-masing anggota dalam satu kelompok melaksanakan tanggung jawab pribadinya karena ada sistem akuntabilitas individu. Siswa tidak bisa begitu saja membonceng jerih payah rekannya dan usaha setiap siswa akan dihargai sesuai dengan poin-poin perbaikannya. Salah satu model yang dapat digunakan yaitu model Jigsaw. Permasalahan yang ingin dikaji dalam dalam penelitian tindakan ini adalah apakah pembelajaran kooperatif model jigsaw berpengaruh terhadap hasil belajar Ilmu Pengetahuan Sosial. Penelitian ini merupakan penelitian tindakan (action research) yang terdiri dari beberapa
\end{abstract}


siklus. Setiap putaran terdiri dari empat tahap yaitu: rancangan, kegiatan dan pengamatan, refleksi, dan revisi. Sasaran penelitian ini adalah siswa kelas Kelas V (lima) SD Negeri 2 Parungsari Tahun Ajaran 2011/2012. Data yang diperoleh berupa hasil tes formatif, lembar observasi kegiatan belajar mengajar. Hasil penelitian didapatkan bahwa prestasi belajar siswa mengalami peningkatan dari siklus I sampai siklus II yaitu, siklus I $(64,71 \%)$, siklus III $(88,24)$.

Kata Kunci: cooperative learning, jigsaw, ilmu pengetahuan social.

\section{A. Pendahuluan}

Sampai saat ini terdapat persepsi umum di dalam dunia pendidikan yaitu tugas guru adalah untuk mengajar dan menyodori siswa dengan muatan-muatan informasi dan pengetahuan. Hal ini menyebabkan guru dipandang sebagai sosok yang maha tahu dan sumber informasi (Ali, 1996). Setidaknya itulah bagaimana pandangan siswa kepada gurunya. Selain itu dalam proses pembelajarannya siswa kadang merasa tertekan karena terbebani oleh tuntutan-tuntutan nilai tes dan ujian yang tinggi. Seiring dengan proses globalisasi, juga terjadi transformasi sosial, ekonomi, dan demografis yang mengharuskan sekolah untuk lebih menyiapkan anak didik dengan keterampilanketerampilan baru untuk bisa ikut berpartisipasi dalam dunia yang berubah dan berkembang pesat.
Dibutuhkan metode mengajar dimana siswa dapat bekerja bersama-sama dengan temantemannya secara berkelompok agar pembelajaran terasa lebih menyenangkan. Hal ini juga bermanfaat dalam mengurangi beban belajar siswa, dimana siswa dapat saling bertukan informasi dan berbagi tugas. Memang tidak bisa disangkal bahwa banyak guru telah sering menugaskan para siswa untuk bekerja dalam kelompok. Sayangnya, metode kerja kelompok sering dianggap kurang efektif. Berbagai sikap dan kesan negative memang bermunculan dalam pelaksaan metode kerja kelompok. Jika kerja kelompok tidak berhasil, siswa cenderung saling menyalahkan. Sebaliknya jika berhasil, muncul perasaan tidak adil. Perasaan adil itu muncul dikarenakan siswa yang pandai/rajin merasa rekannya yang 
Didaktik : Jurnal Pendidikan Guru Sekolah Dasar, ISSN : 24775673

Sekolah Tinggi Keguruan dan IImu Pendidikan Subang

Volume IV Nomor 2, Desember 2018

kurang mampu telah membonceng pada hasil kerja mereka. Akibatnya, metode kerja kelompok yang seharusnya bertujuan mulia, yakni menanamkan rasa persaudaraan dan kemampuan bekerja sama, justru bisa berakhir dengan ketidakpuasaan dan kekecewaaan. Bukan hanya guru dan siswa yang merasa pesimis mengenai penggunaan metode kerja kelompok, bahkan kadang-kadang orang tua pun merasa was-was jika anak mereka dimasukkan dalam satu kelompok dengan siswa lain yang dianggap kurang seimbang. Berbagai dampak negatif dalam menggunakan metode kerja kelompok tersebut seharusnya bisa dihindari jika saja guru mau meluangkan lebih banyak waktu dan perhatian dalam mempersiapkan dan menyusun metode kerja kelompok.

Di dalam pembelajaran guru sering sekali menggunakan metode Cooperative Learning untuk pembelajaran berkelompok. Pada metode pembelajaran cooperative learning bukan hanya sekedar kerja kelompok, melainkan pada penstrukturannya. Metode pembelajaran cooperative learning bisa didefinisikan sebagai pembelajaran berkelompok yang terstruktur, dimana menurut Johnson \& Johnson (1994) terdapat lima unsur pokok dalam struktur ini, yaitu saling ketergantungan positif, tanggung jawab individual, interaksi personal, keahlian bekerja sama, dan proses kelompok. Salah satu model yang memenuhi kelima unsur pokok tersebut yaitu model pembelajaran Jigsaw.

Melalui Jigsaw kelas dibagi menjadi beberapa tim yang anggotanya terdiri dari atau enam siswa dengan karakteristik yang heterogen (Aronson, 2006). Bahan akademik disajikan kepada siswa dalam bentuk teks; dan tiap siswa bertanggung jawab untuk mempelajari suatu bagian dari bahan akademik tersebut. Pada anggota dari berbagai tim yang berbeda memiliki tanggung jawab untuk mempelajari suatu bagian akademik yang sama dan selanjutnya berkumpul untuk saling membantu mengkaji bagian bahan tersebut. Kumpulan siswa semacam itu desebut "kelompok pakar" (expert group). Selanjutnya, 
Didaktik : Jurnal Pendidikan Guru Sekolah Dasar, ISSN : 24775673

Sekolah Tinggi Keguruan dan IImu Pendidikan Subang

Volume IV Nomor 2, Desember 2018

para pakar siswa yang berada

dalam kelompok pakar kembali ke

kelompoknya semula (home teams)

untuk mengajar anggota lain

mengenai materi yang telah

dipelajari dalam kelompok pakar.

Setelah diadakan pertemuan dan

diskusi dalam "home teams", para

siswa dievaluasi secara individual

mengenai bahan yang telah

dipelajari. Individu atau tim yang memperoleh skor tinggi diberi penghargaan oleh guru.

Melalui pembelajaran dengan menggunakan Jigsaw siswa siswa dituntut untuk dapat bekerja sama dengan angota kelompoknya yang lain. Kerja sama pada jigsaw ini bukan hanya bekerja bersamasama mengerjakan hal yang sama, melainkan setiap anggota kelompoknya memiliki tugas masing-masing dan siswa harus dapat bertanggungjawab terhadap tugas yang diberikan tersebut. Sehingga tidak ada siswa yang hanya ikut-ikutan saja atau numpang nama saja. Setiap anggota kelompok harus bertanggungjawab dan menyelesaikan tugasnya. Jika salah satu anggota saja tidak dapat menyelesaikan tugasnya, maka seluruh anggota kelompok akan mengalami kesulitan. Penggunaan model Jigsaw dalam penelitian ini diharapkan dapat meningkatkan hasil belajar siswa teutama dalam pembelajaran IPS pada pokok bahasan "menghargai keragaman suku bangsa dan budaya di Indonesia".

\section{B. Metode Penelitian}

Penelitian ini merupakan penelitian tindakan kelas (classroom action research). Penelitian ini dilakukan untuk memecahkan permasalahan dalam pembelajaran di dalam kelas. Hal ini sesuai dengan karakteristik dari penelitian tindakan kelas yaitu dimana permasalahan penelitian berasal dari permasalahan dalam proses pembeajaran di dalam kelas. Sesuai dengan jenis penelitian yang dipilih, yaitu penelitian tindakan, maka penelitian ini menggunakan model penelitian tindakan dari Kemmis dan Taggart (Arikunto, 1999), yaitu berbentuk spiral dari siklus yang satu ke siklus yang berikutnya. Setiap siklus meliputi planning 
Didaktik : Jurnal Pendidikan Guru Sekolah Dasar, ISSN : 24775673

Sekolah Tinggi Keguruan dan IImu Pendidikan Subang

Volume IV Nomor 2, Desember 2018

(rencana), action (tindakan),

diterapkannya

metode

observation (pengamatan), dan

pembelajaran model jigsaw.

reflection (refleksi). Langkah pada

siklus berikutnya adalah

3. Refleksi, peneliti mengkaji, melihat dan mempertimbangkan

perncanaan yang sudah direvisi, tindakan, pengamatan, dan refleksi.

Penelitian ini dilakukan di SD Negeri 2 Parungsari pada semester ganjil tahun pelajaran 2011/2012 di bulan oktober. Subjek penelitian adalah siswa kelas $\mathrm{V}$ (lima) SD Negeri 2 Parungsari sebanyak 34 siswa dengan pokok bahasan "menghargai keragaman suku bangsa dan budaya di Indonesia".

Adapun prosedur penelitian yang dilakukan adalah sebagai berikut:

1. Rancangan/rencana awal, sebelum mengadakan penelitian peneliti menyusun rumusan masalah, tujuan dan membuat rencana tindakan, termasuk di dalamnya instrumen penelitian dan perangkat pembelajaran.

2. Kegiatan dan pengamatan, meliputi tindakan yang dilakukan oleh peneliti sebagai upaya membangun pemahaman konsep siswa serta mengamati hasil atau dampak dari hasil atau dampak dari tindakan yang dilakukan berdasarkan lembar pengamatan yang diisi oleh pengamat.

4. Rancangan/rencana yang direvisi, berdasarkan hasil refleksi dari pengamat membuat rancangan yang direvisi untuk dilaksanakan pada siklus berikutnya.

Observasi dibagi dalam dua putaran, yaitu putaran 1 dan 2, dimana masing putaran dikenai perlakuan yang sama (alur kegiatan yang sama) dan membahas satu sub pokok bahasan yang diakhiri dengan tes formatif di akhir masing putaran. Dibuat dalam dua putaran dimaksudkan untuk memperbaiki sistem pengajaran yang telah dilaksanakan.

Instrument yang digunakan dalam penelitian ini yaitu:

1. Rencana pembelajaran (RPP)

Merupakan perangkat pembelajaran yang digunakan sebagai pedoman guru dalam mengajar dan disusun untuk tiap 
Didaktik : Jurnal Pendidikan Guru Sekolah Dasar, ISSN : 24775673

putaran. Masing-masing RP berisi kompetensi dasar, indikator pencapaian hasil belajar, tujuan pembelajaran khusus, dan kegiatan belajar mengajar.

2. Lembar Kegiatan Siswa (LKS) Lembar kegiatan siswa ini digunakan oleh siswa untuk membantu proses pembelajaran serta digunakan oleh peneliti untuk pengumpulan data hasil kegiatan belajar mengajar.

3. Tes Formatif

Tes ini disusun berdasarkan tujuan pembelajaran yang akan dicapai, digunakan untuk mengukur kemampuan pemahaman konsep IImu Pengetahuan Sosial. Tes formatif ini diberikan setiap akhir putaran. Bentuk soal yang diberikan adalah pilihan guru (objektif). Sebelumnya soal-soal ini berjumlah 46 soal yang telah diujicoba dan dilakukan analisis butir soal.

C. Hasil Penelitian

Siklus I

1. Tahap Perencanaan
Pada tahap ini peneliti

mempersiapkan perangkat

pembelajaran yang terdiri dari

rencana pelajaran 1 , soal tes

formatif 1 dan alat-alat pengajaran yang mendukung.

2. Tahap Kegiatan dan

Pelaksanaan

Pelaksanaan kegiatan belajar mengajar untuk siklus I dilaksanakan pada tanggal 19 Oktober 2011 di Kelas V (lima) SD Negeri 2 Parungsari dengan jumlah siswa 34 siswa. Adapun proses belajar mengajar mengacu pada rencana pelajaran yang telah dipersiapkan. Pengamatan (observasi) dilaksanakan bersamaan dengan pelaksaaan belajar mengajar

Pada akhir proses belajar mengajar siswa diberi tes formatif 1 dengan tujuan untuk mengetahui tingkat keberhasilan siswa dalam proses belajar mengajar yang telah dilakukan. Adapun data hasil penelitian pada siklus I adalah sebagai berikut: 
Didaktik : Jurnal Pendidikan Guru Sekolah Dasar, ISSN : 24775673

Sekolah Tinggi Keguruan dan IImu Pendidikan Subang

Volume IV Nomor 2, Desember 2018

Table 1. Nilai Tes Formatif Pada Siklus I

\begin{tabular}{|c|c|c|c|c|c|c|c|}
\hline \multirow{2}{*}{ No. Urut } & \multirow{2}{*}{ Nilai } & \multicolumn{2}{|c|}{ Keterangan } & \multirow{2}{*}{ No. Urut } & \multirow{2}{*}{ Nilai } & \multicolumn{2}{|c|}{ Keterangan } \\
\cline { 7 - 9 } & & $\mathrm{T}$ & $\mathrm{TT}$ & & & $\mathrm{T}$ & $\mathrm{TT}$ \\
\hline 1 & 60 & & $\sqrt{ }$ & 15 & 60 & & $\sqrt{ }$ \\
\hline 2 & 50 & $\sqrt{ }$ & & 16 & 70 & $\sqrt{ }$ & \\
\hline 3 & 80 & $\sqrt{ }$ & & 17 & 70 & $\sqrt{ }$ & \\
\hline 4 & 70 & $\sqrt{ }$ & & 18 & 80 & $\sqrt{ }$ & \\
\hline 5 & 60 & $\sqrt{ }$ & & 19 & 70 & $\sqrt{ }$ & \\
\hline 6 & 80 & $\sqrt{ }$ & & 20 & 50 & & $\sqrt{ }$ \\
\hline 7 & 50 & $\sqrt{ }$ & & 21 & 70 & $\sqrt{ }$ & \\
\hline 8 & 70 & & $\sqrt{ }$ & 22 & 70 & $\sqrt{ }$ & \\
\hline 9 & 80 & $\sqrt{ }$ & & 23 & 60 & & $\sqrt{ }$ \\
\hline 10 & 50 & $\sqrt{ }$ & & 24 & 80 & $\sqrt{ }$ & \\
\hline 11 & 60 & $\sqrt{ }$ & & 25 & 70 & $\sqrt{ }$ & \\
\hline 12 & 60 & $\sqrt{ }$ & 26 & 60 & & $\sqrt{ }$ \\
\hline 13 & 80 & $\sqrt{ }$ & & 27 & 70 & $\sqrt{ }$ & \\
\hline 14 & 70 & $\sqrt{ }$ & & 28 & 80 & $\sqrt{ }$ & \\
\hline Jml & 920 & 12 & 2 & Jml & 960 & 10 & 4 \\
\hline Rata-Rata Skor Tercapai 67,14 & & & & \\
\hline
\end{tabular}

Keterangan:

$\mathrm{T}$

TT

Jumlah siswa yang tuntas

Jumlah siswa yang belum tuntas

Klasikal
: Tuntas

: Tidak Tuntas

$: 22$

$: 12$

: Belum tuntas

Tabel 2. Rekapitulasi Hasil Tes Formatif Siswa Pada Siklus I

\begin{tabular}{|c|l|c|}
\hline No & \multicolumn{1}{|c|}{ Uraian } & Hasil Siklus I \\
\hline 1 & Nilai rata-rata tes formatif & 67,14 \\
2 & Jumlah siswa yang tuntas belajar & 22 \\
3 & Persentase ketuntasan belajar & 64,71 \\
\hline
\end{tabular}

Dari tabel di atas dapat kooperatif model jigsaw diperoleh dijelaskan bahwa dengan nilai rata-rata prestasi belajar siswa menerapkan pembelajaran adalah 67,14 dan ketuntasan 
belajar mencapai $64,71 \%$ atau ada

22 siswa dari 34 siswa sudah tuntas belajar. Hasil tersebut menunjukkan bahwa pada siklus pertama secara klasikal siswa belum tuntas belajar, karena siswa yang memperoleh nilai $\geq 65$ hanya sebesar $60,71 \%$ lebih kecil dari persentase ketuntasan yang dikehendaki yaitu sebesar $85 \%$. Hal ini disebabkan karena siswa masih baru dan asing terhadap metode baru yang diterapkan dalam proses belajar mengajar.

\section{Refleksi}

Dalam pelaksanaan kegiatan belajar mengajar diperoleh informasi dari hasil pengamatan sebagai berikut:

a) Guru kurang baik dalam memotivasi siswa dan dalam menyampaikan tujuan pembelajaran

b) Guru kurang baik dalam pengelolaan waktu

c) Siswa kurang begitu antusias selama pembelajaran berlangsung.

4. Revisi

Pelaksanaan kegiatan belajar mengajar pada siklus I ini masih terdapat kekurangan, sehingga perlu adanya refisi untuk dilakukan pada siklus berikutnya.

1) Guru perlu lebih terampil dalam memotivasi siswa dan lebih jelas dalam menyampaikan tujuan pembelajaran. Dimana siswa diajak untuk terlibat langsung dalam setiap kegiatan yang akan dilakukan.

2) Guru perlu mendistribusikan waktu secara baik dengan menambahkan informasiinformasi yang dirasa perlu dan memberi catatan

3) Guru harus lebih terampil dan bersemangat dalam memotivasi siswa sehingga siswa bisa lebih antusias.

Siklus II

\section{Tahap Perencanaan}

Pada tahap ini peneliti mempersiapkan perangkat pembelajaran yang terdiri dari rencana pelajaran 2, soal tes formatif 2 dan alat-alat pengajaran yang mendukung.

2. Tahap kegiatan dan pengamatan

Pelaksanaan kegiatan belajar mengajar untuk siklus III dilaksanakan pada tanggal 24 
Didaktik : Jurnal Pendidikan Guru Sekolah Dasar, ISSN : 24775673

Sekolah Tinggi Keguruan dan IImu Pendidikan Subang

Volume IV Nomor 2, Desember 2018

Oktober 2011 di Kelas V (lima) SD

Negeri 2 Parungsari dengan jumlah

siswa 34 siswa. Dalam hal ini peneliti bertindak sebagai guru.

Adapun proses belajar mengajar mengacu pada rencana pelajaran dengan memperhatikan revisi pada siklus I, sehingga kesalahan atau kekurangan pada siklus I tidak terulang lagi pada siklus II. Pengamatan

(observasi) dilaksanakan bersamaan dengan pelaksanaan belajar mengajar.

Pada akhir proses belajar mengajar siswa diberi tes formatif 2 dengan tujuan untuk mengetahui tingkat keberhasilan siswa dalam proses belajar mengajar yang telah dilakukan. Instrumen yang digunakan adalah tes formatif II. Adapun data hasil penelitian pada siklus II adalah sebagai berikut:

Table 3. Nilai Tes Formatif Pada Siklus II

\begin{tabular}{|c|c|c|c|c|c|c|c|}
\hline \multirow{2}{*}{ No. Urut } & \multirow{2}{*}{ Nilai } & \multicolumn{2}{|c|}{ Keterangan } & \multirow{2}{*}{ No. Urut } & \multirow{2}{*}{ Nilai } & \multicolumn{2}{|c|}{ Keterangan } \\
\hline & & $\bar{T}$ & TT & & & $\mathrm{T}$ & TT \\
\hline 1 & 60 & & $\sqrt{ }$ & 15 & 80 & $\sqrt{ }$ & \\
\hline 2 & 80 & $\sqrt{ }$ & & 16 & 90 & $\sqrt{ }$ & \\
\hline 3 & 80 & $\sqrt{ }$ & & 17 & 80 & $\sqrt{ }$ & \\
\hline 4 & 70 & $\sqrt{ }$ & & 18 & 70 & $\sqrt{ }$ & \\
\hline 5 & 70 & $\sqrt{ }$ & & 19 & 80 & $\sqrt{ }$ & \\
\hline 6 & 90 & $\sqrt{ }$ & & 20 & 60 & & $\sqrt{ }$ \\
\hline 7 & 80 & $\sqrt{ }$ & & 21 & 80 & $\sqrt{ }$ & \\
\hline 8 & 60 & & $\sqrt{ }$ & 22 & 90 & $\sqrt{ }$ & \\
\hline 9 & 80 & $\sqrt{ }$ & & 23 & 80 & $\sqrt{ }$ & \\
\hline 10 & 90 & $\sqrt{ }$ & & 24 & 70 & $\sqrt{ }$ & \\
\hline 11 & 70 & $\sqrt{ }$ & & 25 & 80 & $\sqrt{ }$ & \\
\hline 12 & 80 & $\sqrt{ }$ & & 26 & 70 & $\sqrt{ }$ & \\
\hline 13 & 90 & $\sqrt{ }$ & & 27 & 70 & $\sqrt{ }$ & \\
\hline 14 & 70 & $\sqrt{ }$ & & 28 & 90 & $\sqrt{ }$ & \\
\hline Jml & 1070 & 12 & 2 & Jml & 1090 & 13 & 1 \\
\hline
\end{tabular}


Keterangan:

$\mathrm{T}$

TT

Jumlah siswa yang tuntas

Jumlah siswa yang belum tun

Klasikal
: Tuntas

: Tidak Tuntas

$: 30$

$: 4$

: Tuntas

Tabel 4. Hasil Tes Formatif Siswa Pada Siklus III

\begin{tabular}{|c|l|c|}
\hline No & \multicolumn{1}{|c|}{ Uraian } & Hasil Siklus III \\
\hline 1 & Nilai rata-rata tes formatif & 77,14 \\
2 & Jumlah siswa yang tuntas belajar & 30 \\
3 & Persentase ketuntasan belajar & 88,24 \\
\hline
\end{tabular}

Berdasarkan tabel diatas diperoleh nilai rata-rata tes formatif sebesar 77,14 dan dari 34 siswa yang telah tuntas sebanyak 30 siswa dan 4 siswa belum mencapai ketuntasan belajar. Maka secara klasikal ketuntasan belajar yang telah tercapai sebesar 88,24\% (termasuk kategori tuntas). Hasil pada siklus II ini mengalami peningkatan lebih baik dari siklus I. Adanya peningkatan hasil belajar pada siklus II ini dipengaruhi oleh adanya peningkatan kemampuan siswa dalam mempelajari materi pelajaran yang telah diterapkan selama ini serta ada tanggung jawab kelompok dari siswa yang lebih mampu untuk mengajari temannya kurang mampu.

\section{Refleksi}

Pada tahap ini akah dikaji apa yang telah terlaksana dengan baik maupun yang masih kurang baik dalam proses belajar mengajar dengan penerapan pembelajaran kooperatif model jigsaw. Dari datadata yang telah diperoleh dapat duraikan sebagai berikut:

a. Selama proses belajar mengajar guru telah melaksanakan semua pembelajaran dengan baik. Meskipun ada beberapa aspek yang belum sempurna, tetapi persentase pelaksanaannya untuk masing-masing aspek cukup besar.

b. Berdasarkan data hasil pengamatan diketahui bahwa 
Didaktik : Jurnal Pendidikan Guru Sekolah Dasar, ISSN : 24775673

Sekolah Tinggi Keguruan dan IImu Pendidikan Subang

Volume IV Nomor 2, Desember 2018

siswa aktif selama proses belajar berlangsung.

c. Kekurangan pada siklus-siklus sebelumnya sudah mengalami perbaikan dan peningkatan sehingga menjadi lebih baik.

d. Hasil belajar siswa pada siklus III mencapai ketuntasan.

4. Revisi Pelaksanaan

Pada siklus II guru telah menerapkan pembelajaran kooperatif model jigsaw dengan baik dan dilihat dari aktivitas siswa serta hasil belajar siswa pelaksanaan proses belajar mengajar sudah berjalan dengan baik. Maka tidak diperlukan revisi terlalu banyak, tetapi yang perlu diperhatikan untuk tindakah selanjutnya adalah

memaksimalkan dan mempertahankan apa yang telah ada dengan tujuan agar pada pelaksanaan proses belajar mengajar selanjutnya penerapan pembelajaran kooperatif model jigsaw dapat meningkatkan proses belajar mengajar sehingga tujuan pembelajaran dapat tercapai.

Melalui hasil peneilitian ini menunjukkan bahwa pembelajaran kooperatif model jigsaw memiliki dampak positif dalam meningkatkan hasil belajar siswa. Hal ini dapat dilihat dari semakin mantapnya pemahaman dan penguasaan siswa terhadap materi yang telah disampaikan guru selama ini (ketuntasan belajar meningkat dari siklus I dan II) yaitu masing-masing $\quad 64,71 \%$ dan $88,24 \%$. Pada siklus II ketuntasan belajar siswa secara klasikal telah tercapai.

Berdasarkan analisis data, diperoleh aktivitas siswa dalam proses pembelajaran kooperatif model jigsaw dalam setiap siklus mengalami peningkatan. Hal ini berdampak positif dalam peningkatan prestasi belajar siswa, yaitu dapat ditunjukkan dengan meningkatnya nilai rata-rata siswa pada setiap siklus yang terus mengalami peningkatan.

Berdasarkan analisis data, diperoleh aktivitas siswa dalam proses pembelajaran IImu Pengetahuan Sosial dengan pembelajaran kooperatif model jigsaw yang paling dominan adalah, mendengarkan/memperhatikan penjelasan guru, dan diskusi antar siswa/antara siswa dengan guru. 
Didaktik : Jurnal Pendidikan Guru Sekolah Dasar, ISSN : 24775673

Sekolah Tinggi Keguruan dan IImu Pendidikan Subang

Volume IV Nomor 2, Desember 2018

Jadi dapat dikatakan bahwa

aktivitas isiswa dapat dikategorikan aktif.

Sedangkan untuk aktivitas guru selama pembelajaran telah melaksanakan langkah-langkah pembelajaran kooperatif model jigsaw dengan baik. Hal ini terlihat dari aktivitas guru yang muncul di antaranya aktivitas membimbing dan mengamati siswa dalam mengerjakan kegiatan,

menjelaskan/melatih

menggunakan alat, memberi umpan balik/evaluasi/tanya jawab dimana prosentase untuk aktivitas di atas cukup besar.

\section{Kesimpulan}

Dari hasil kegiatan pembelajaran yang telah dilakukan, dan berdasarkan seluruh pembahasan serta analisis yang telah dilakukan dapat disimpulkan bahwa Penerapan pembelajaran kooperatif model jigsaw memiliki dampak positif dalam meningkatkan prestasi belajar siswa yang ditandai dengan peningkatan ketuntasan belajar siswa dalam setiap siklus.
Penerapan pembelajaran kooperatif model jigsaw juga mempunyai pengaruh positif, yaitu dapat meningkatkan motivasi belajar siswa untuk mempelajari kembali materi pelajaran yang telah diterima. Selain itu Pembelajaran kooperatif model jigsaw memiliki dampak positif terhadap kerjasama antara siswa, hal ini ditunjukkan adanya tanggung jawab dalam kelompok dimana siswa yang lebih mampu mengajari temannya yang kurang mampu.

\section{DAFTAR PUSTAKA}

Ali, M. 1996. Guru Dalam Proses Belajar Mengajar. Bandung: Sinar Baru Algesindon.

Arikunto, S. 1999. Prosedur Penelitian Suatu Pendekatan Praktek. Jakarta: Rineksa Cipta.

Aronson, E. 2006. The Jigsaw Classroom, Web Site Copyright 2000-2006, Social Psycology Network. http://www.jigsaw.org

Johnson, D. W. \& Johnson, R. T. (1994). Learning together and alone, Cooperative, Competitive, and individualistic learning (4th ed.). Boston: Allyn and Bacon.

Rusman, 2010. Model-model Pembelajaran Mengembangkan Profesionalisme Guru. Depok. Rajawali Pers 